\title{
Pengembangan Media Majamat pada Materi Pecahan Pada Mata Pelajaran Matematika
}

\author{
Eka Novita Pujianingtias ${ }^{1 *}$, Henry Januar Saputra ${ }^{2}$, Muhajir $^{3}$ \\ 13Jurusan Pendidikan Guru Sekolah Dasar, Universitas PGRI Semarang \\ 2 Jurusan Pendidikan Biologi,Universitas PGRI Semarang
}

\begin{abstract}
Abstrak
Tujuan dari penelitian ini adalah untuk Mengembangangkan media MAJAMAT pada materi pecahan kelas V SDN Sitirejo Kabupaten Blora. Jenis penelitian yang digunakan adalah penelitian dan pengembangan atau Research and Development (R\&D). Teknik pengumpulan data menggunakan angket kebutuhan guru dan angket kebutuhan siswa, penilaian validasi ahli materi pembelajaran dan ahli media pembelajaran, angket respon guru dan angket respon siswa. Hasil penilaian rata-rata validasi ahli materi dan ahli media pembelajaran adalah sebesar 93,1\%. Nilai tersebut berada pada interval 81\%-100\% dengan kategori "sangat layak digunakan". Artinya media MAJAMAT layak digunakan sebagai media pembelajaran matematika di SD. Media pembelajaran MAJAMAT mendapatkan respon dari guru sebesar $90 \%$ berdasarkan angket respon guru, dan media juga mendapatka respon siswa sebesar 90,58\%. Kedua nilai tersebut terletak pada interval 81\%-100\% dan termasuk kategori "sangat layak digunakan". Artinya media MAJAMAT layak digunakan sebagai media pembelajaran matematika di SD dan dapat diterima oleh guru maupun siswa kelas V SD.
\end{abstract}

Keywords:

Development, Media

Majamat

\section{PENDAHULUAN}

Secara bahasa definisi pendidikan mengandung arti bimbingan yang dilakukan oleh seseorang (orang dewasa) kepada anak-anak, untuk memberikan pengajaran, perbaikan moral dan melatih intelektual. Bimbingan kepada anak-anak dapat dilakukan tidak hanya dalam pendidikan formal yang diselenggarakan pemerintah, akan tetapi peran keluarga dan masyarakat dapat menjadi lembaga pembimbing yang mampu menumbuhkan pemahaman dan pengetahuan. Berperannya keluarga dan masyarakat dalam melakukan bimbingan pengetahuan, sejalan dengan definisi pendidikan menurut Edgar Dalle yang menjelaskan bahwa pendidikan sebagai usaha sadar yang dilakukan oleh $1 \mathrm{Abu}$ Ahmadi dan Nur Uhbiyati. 2007. Ilmu Pendidikan. Jakarta: Rineka Cipta. hlm. 67. 2 Abdul Kadir, dkk. 2012. Dasar-dasar Pendidikan. Jakarta: Kharisma. hlm. 59. 3 Abdul Kadir, dkk. 2012. hlm. 59. keluarga, masyarakat, dan pemerintah melalui kegiatan bimbingan, pengajaran, dan latihan yang berlangsung di sekolah dan di luar sekolah sepanjang hayat untuk mempersiapkan peserta didik agar dapat memainkan peranan dalam berbagai lingkungan hidup secara tetap untuk masa yang akan dating (Siti, 2018).

Pendidikan adalah proses perubahan tingkah laku, penambahan ilmu pengetahuan dan pengalaman hidup agar peserta didik menjadi lebih dewasa dalam pemikiran dan sikap. Pendidikan di era digital saat ini sangatlah pesat, kemajuan dalam bidang teknologi tidak hanya dinikmati oleh orang dewasa saja, anak-anak usia sekolah dasar juga sudah bisa menikmati dari hasil perkembangan teknologi saat ini. Teknologi banyak dimanfaatkan dalam dunia pendidikan, sebagai sarana dan prasarana interaksi antara pendidik dan peserta didik. Perkembangan teknologi saat ini mempunyai dampak positif dan damapak negatif, sebaiknya dampak positif lebih dominan dimanfaatkan oleh pengguna teknologi. 
Munculnya banyak kasus yang destruktif dalam konteks kebangsaan, misalnya terjadinya sentimen antar etnis, perselisihan antar suku, kasus-kasus narkoba, tawuran antar pelajar, kekerasan terhadap anak, begal di mana-mana, kasus Bullying, menunjukkan karakter kebangsaan yang lemah. Pembentukan karakter sedari dini akan menumbuhkan budaya karakter bangsa yang baik dan kunci utama dalam membangun bangsa. Pendidikan karakter bertujuan agar peserta didik sebagai penerus bangsa mempunyai akhak dan moral yang baik, untuk menciptakan kehiupan berbangsan yang adil, aman dan makmur. Tujuan Pendidikan dalam Undang Undang Nomor 20 tahun 2003 tentang Sistem Pendidikan Nasional yang menyebutkan bahwa "Pendidikan nasional berfungsi mengembangkan kemampuan dan membentuk watak serta peradaban bangsa yang bermartabat dalam rangka mencerdaskan kehidupan bangsa, bertujuan untuk berkembangnya potensi peserta didik agar menjadi manusia yang beriman dan bertaqwa kepada Tuhan Yang Maha Esa, berakhlak mulia, sehat, berilmu, cakap, kreatif, mandiri dan menjadi warga negara yang demokratis serta bertanggung jawab (Palupi, 2018).

Pasal 1 UU SISDIKNAS no. 20 tahun 2003 disebutkan bahwa Sistem Pendidikan Nasional adalah keseluruhan komponen pendidikan yang saling terkait secara terpadu untuk mencapai tujuan pendidikan nasional. Berangkat dari bunyi pasal ini dapat diketahui bahwa pendidikan adalah sistem yang merupakan suatu totalitas struktur yang terdiri dari komponen yang saling terkait dan secara bersama menuju kepada tercapainya tujuan (Soetarno, 2003: 2). Adapun komponen-komponen dalam pendidikan nasional antara lain adalah lingkungan, sarana-prasarana, sumberdaya, dan masyarakat. Komponenkomponen tersebut bekerja secara bersama-sama, saling terkait dan mendukung dalam mencapai tujuan pendidikan. Tujuan pendidikan nasional yang dirumuskan dalam UU SISDIKNAS adalah untuk mengembangkan potensi anak didik agar menjadi manusia yang beriman dan bertakwa kepada Tuhan Yang Maha Esa, berakhlak mulia, sehat, berilmu, cakap, kreatif, mandiri, dan menjadi warga Negara yang demokratis serta bertanggung jawab (Minirah, 2015).

Kemajuan bangsa Indonesia diperoleh melalui penataan pendidikan yang baik, dengan adanya berbagai upaya peningkatan mutu pendidikan diharapkan dapat meningkatkan harkat dan martabat manusia indonesia. Untuk mencapai tujuan tersebut, maka pemerintah melakukan pembaharuan pendidikan di Indonesia, pembaharuan pendidikan di Indonesia perlu terus dilakukan untuk menciptakan dunia pendidikan yang siap akan perubahan zaman.

Berbagai upaya yang telah ditempuh oleh pemerintah dalam meningkatkan kualitas pendidikan di Indonesia adalah : Pembaharuan dalam Kurikulum, Pengembangan model pembelajaran, perubahan sistem penilaian dan lain sebagainya. Pendidikan merupakan suatu keharusan yang harus didapat oleh masing masing individu bahkan dizaman sekarang ini. Orang dapat mencapai keinginannya melalui pendidikan semakin tinggi pendidikannya maka semakin tinggi pula keinginan yang tumbuh dari dalam diri.

Hadi (2005, pp.11-12) menyatakan bahwa proses pembelajaran mtematika selama ini yang terjadi belum sesuai dengan yang diharapkan, yaitu masih berpusat pada guru.Selama ini siswa hanya duduk diam sambil mendengarkan penjelasan dari gurunya kemudian mencatat kembali apa yang dicatat oleh guru di depan kelas atau papan tulis selanjutnya mengerjakan soal latihan yang soal dan penyelesaiannya tidak berbeda jauh dengan apa yang dicontohkan oleh guru di depan kelas. Dominasi guru dalam proses pembelajaran menyebabkan kecenderungan siswa lebih bersifat pasif, interaksi dalam kelas hanya satu arah, sehingga mereka lebih banyak menunggu sajian guru daripada mencari dan menemukan sendiri pengetahuan, ketrampilan, atau sikap yang mereka butuhkan. Begitu pula dengan pengetahuan yang dimiliki oleh siswa hanya terbatas pada apa yang telah diajarkan oleh guru saja.Kondisi ini mengakibatkan mata pelajaran matematika masih dipandang sebagai mata pelajaran yang sulit oleh siswa maupun masyarakat pada umumnya (Muijs \& Reynolds, 2005, p.212) (Alin, 2105).

Sesuai dengan UUD 1945 yang menyangkut pendidikan adalah alenia keempat yang berbunyi mencerdaskan kehidupan bangsa. Dengan demikian menjadi jelas bahwa mendidik merupakan suatu hal yang bertujuan mencerdaskan bangsa. Menurut Undang - undang Republik Indonesia No.20 tahun 2003 tentang sistem pendidikan Nasional.

Pendidikan adalah usaha sadar dan terencana untuk mewujudkan suasana belajar dan proses pembelajaran agar peserta didik mengembangkan potensi dirinya untuk memiliki kekuatan spiritual keagaman, pengendalian diri, kepribadian, kecerdasan, akhlak mulia serta keterampilan yang diperlukan dirinya, masyarakat, bangsa dan negara.

Tercapainya tujuan pendidikan dipengaruhi oleh beberapa faktor antara lain dapat melalui keluarga, lingkungan dan sekolah. Suasana kelas dan keadaan kelas yang kondusif dan efektif juga dapat mempengaruhi peningkatan kegiatan belajar mengajar yang ada di kelas. Kondisi kelas yang kondusif dan efektif merupakan tanggung jawab oeh seorang guru untuk menciptakan suasana kelas yang seperti itu agar peserta didik memiliki semangat dan antusias belajar yang tinggi. 
Menurut Sudjana dan Rivai (2017:1) “Tujuan pendidikan pada dasarnya mengantarkan para siswa menuju pada perubahan- perubahan tingkah laku baik intelektual, moral maupun sosial agar mereka dapat hidup mandiri sebagai individu dan makhluk sosial".

Seorang guru harus bisa memberikan perubahan-perubahan dalam pembelajaran agar siswa tidak bosan dalam belajar dikelas, sehingga tujuan pembelajaran dapat tercapai, seorang guru harus dapat menyampaikan informasi dengan jelas kepada siswa agar siswa dapat dengan mudah memahami informasi berupa materi yang disampaikan oleh guru secara jelas. Dengan demikian dalam proses pembelajaran diperlukan alat atau media sebagai perantara dalam menyampaikan materi agar pada proses belajar mengajar tidak monoton. Selain media yang digunakan seorang guru harus dapat menguasai materi dan memiliki pengetahuan yang luas dibanding siswa hal ini agar guru dapat menguasai kelas.

Guru menjadi faktor yang menentukan mutu pendidikan karena guru berhadapan langsung dengan para peserta didik dalam proses pembelajaran di kelas. Di tangan guru, mutu dan kepribadian peserta didik dibentuk. Karena itu, perlu sosok guru kompeten, bertanggung jawab, terampil, dan berdedikasi tinggi. Guru adalah kurikulum berjalan. Sebaik apa kurikulum dan sistem pendidikan yang ada tanpa didukung oleh kemampuan guru, semuanya akan sia-sia. Guru berkompeten dan bertanggung jawab, utamanya dalam mengawal perkembangan peserta didik sampai ke suatu titik maksimal. Tujuan akhir seluruh proses pendampingan guru adalah tumbuhnya pribadi dewasa yang utuh. Seiring dengan kemajuan teknologi informasi yang begitu pesat, guru tidak lagi sekedar bertindak sebagai penyaji informasi. Guru juga harus mampu bertindak sebagai fasilitator, motivator, dan pembimbing yang lebih banyak memberikan kesempatan kepada peserta didik untuk mencari dan mengolah sendiri informasi (Uno, 2009:16-17).

Dengan demikian, guru juga harus senantiasa meningkatkan keahliannya dan senantiasa mengikuti perkembangan ilmu pengetahuan dan teknologi sehingga ia mampu menghadapi berbagai tantangan. Perkembangan dunia pendidikan yang sejalan dengan kemajuan teknologi dan globalisasi yang begitu cepat perlu diimbangi oleh kemampuan pelaku utama pendidikan, dalam hal ini guru. Bagi sebagian guru, menghadapi perubahan yang cepat dalam pendidikan dapat membawa dampak kecemasan dan ketakutan. Perubahan dan pembaruan pada umumnya membawa banyak kecemasan dan ketidaknyamanan. Implikasi perubahan dalam dunia pendidikan, bukan perkara mudah, karena mengandung konsekwensi teknis dan praksis, serta psikologis bagi guru. Misalnya, perubahan kurikulum atau perubahan kebijakan pendidikan. Perubahan itu tidak sekedar perubahan struktur dan isi kurikulum (Shabir , 2015).

Media pembelajaran memiliki peranan penting dalam kegiatan belajar mengajar dikelas dalam meningkatkan hasil belajar dan pemahaman siswa, selain itu media pembelajaran mampu mempermudah guru dalam menyampaikan materi agar lebih menyenangkan di kelas. Namun, realita dilapangan sangat berbeda dengan teori yang telah dipelajari oleh calon guru yang sedang menempuh pendidikan dibangku perkuliahan yang mana kebanyakan guru saat mangajar didalam kelas tidak menggunakan media, namun mereka lebih banyak menggunakan metode ceramah atau pembelajaran konvensional. Hal tersebut dikarenakan kebanyakan guru tidak mau repot saat membuat media. Sehingga sekarang ini guru dituntut harus kreatif agar pembelajaran dikelas tidak monoton.

Pengertian media pembelajaran anatara lain disampaikan oleh beberapa pakar pendidikan. Mulyani Sumantri (2000: 125) menuliskan: menurut Bringgs (1970) ialah segala alat fisik yang dapat menyajikan pesan serta perangsang peserta didik untuk belajar, contoh buku, film, kaset. Aristo Rahardi (2003: 9) menuliskan menurut Asosiasi Teknologi Komunikasi Pendidikan (AECT), media pembelajaran adalah segala sesuatu yang digunakan orang untuk menyalurkan pesan. Sedangkan Noehi Nasution (2004: 7) menuliskan media pembelajaran menurut (1) Gagne, media pembelajaran sebagai komponen sumber belajar di lingkungan siswa yang dapat merangsang siswa untuk belajar, (2) Briggs, media pembelajaran adalah wahana fisik yang mengandung materi pelajaran dan (3) Wilbur Schramm, media pembelajaran adalah teknik pembawa informasi atau pesan pembelajaran. Yusuf Hadi Miarso: media pembelajaran adalah segala sesuatu yang dapat merangsang terjadi nya proses belajar mengajar. (Rohman, 2013: 156) Dengan memperhatikan berbagai definisi diatas dapat disimpulkan bahwa media pembelajaran adalah segala sesuatu baik berupa fisik maupun teknis dalam proses pembelajaran yang dapat membantu guru untuk mempermudah dalam menyampaikan materi pelajaran kepada siswa sehingga memudahkan pencapaian tujuan pembelajaran yang telah dirumuskan (Adam, 2015).

Berdasarkan hasil wawancara yang dilakukan oleh penulis pada hari kamis, 27 September 2018 di SDN Sitirejo Kabupaten Blora dengan narasumber Ibu Siti Sulikah,S.Pd.,SD guru kelas 5 beliau mengatakan bahwa di SDN Sitirejo Kabupaten Blora dengan jumlah 31 siswa masih setengah siswa yang memiliki nilai dibawah KKM pada mata pelajaran Matematika dengan KKM 70. Jika persenkan menjadi 51,6 siswa yang memiliki nilai masih dibawah kkm. Hal ini dikarenakan siswa masih kurang aktif pada 
saat pembelajaran disebabkan adanya kejenuhan siswa pada pembelajaran khususnya pada mata pelajaran matematika. Pada mata pelajaran matematika siswa selalu diam kalau guru tidak menunjuk siswa untuk maju kedepan kelas untuk mengerjakan soal yang ada dipapan tulis hal lain yang mempengaruhi adalah guru masih susah dalam mengaplikasikan media kedalam pembelajaran sehingga peserta didik hanya mengandalkan penjelasan guru sebagai sumber informasi utama

Untuk mengatasi permasalahan tersebut peneliti melakukan penelitian dengan mengembangkan media Majamat (Majalah Matematika) dalam materi pecahan, pada pengembangan media ini siswa diajak untuk aktif dalam menggali informasi. Selain itu melalui media ini siswa diajak untuk berkerja kelompok dengan membentuk kelompok hal ini bertujuan untuk melatih keterampilan komunikasi siswa selain itu melatih aspek kognitif, afektif dan psikomotorik siswa. Agar tujuan dalam pendidikan dapat terimplementasikan yaitu mengantarkan peserta didik pada perubahan-perubahan tingkah laku baik intelektual, moral maupun sosial agar mereka dapat hidup mandiri sebagai makhluk individu dan makhluk sosial.

Berdasarkan permasalahan yang diperoleh oleh penulis melalui wawancara, maka penulis melakukan penelitian pengembangan dengan judul "Pengembangan Media MAJAMAT Pada Materi Pecahan Pada Mata Pelajaran Matematika Kelas V SDN Sitirejo Kabupaten Blora".

\section{METODE PENELITIAN}

Metode yang akan digunakan dalam penelitian ini adalah metode research and development( R\&D) yaitu rangkaian proses mengembangkan sebuah produk baru atau menyempurnakan produk yang sudah ada. Menurut sugiyono (2011: 297) menyatakan bahwa metode penelitian dan pengembangan atau dalam bahasa inggrisnya Research and development adalah metode penelitian yang digunakan untuk menghasilkan produk tertetu dan menguji keefektifan produk tersebut. Pada intinya metode penelitian dan pengembangan, peneliti harus bisa berinovasi atau membuat sebuah produk dan menghasilkan produk akhir setelah dilakukan validasi, uji coba dan revisi produk oleh ahli materi dan ahli.

Desain pengembangan media MAJAMAT ini dilakukan berdasarkan tahapan langkah-langkah pengembangan yang dikemukakan oleh Sugiyono (2011: 298-311), yaitu: Potensi dan Masalah, Pengumpulan Informasi, Desain Produk, Validasi Desain, Perbaikan Desain, Uji Coba Produk, Revisi Produk, Uji Coba Pemakaian, Revisi Produk, Pembuatan Produk Masal. Berdasarkan buku pedoman skripsi FIP Universitas PGRI Semarang menyatakan bahwa langkah/prosedur penelitian pengembangan S1 yaitu: pengembangan Produk atau desain produk, Validasi ahli media dan materi, revisi produk, Uji coba terbatas, Revisi produk (Jika ada), Penerapan media/produk.

\section{ANALISIS DAN PEMBAHASAN}

Berdasarkan hasil Studi pendahuluan angket kebutuhan siswa diketahui bahwa kebutuhan peserta didik terhadap media media pembelajaran sangatlah diperlukan. Angket analisis kebutuhan peserta didik dilakukan pada kelas V di SDN Sitirejo Kecamatan tujungan kabupaten Blora dengan jumlah responden 31 siswa. Pada tabel 4.1 diketahui bahawa sebanyak 96,7\% siswa memahami materi pecahan dengan menjawab "iya", namun hal ini berbeda dengan hasil wawancara yang dilakukan bersama guru. Sebanyak $54,8 \%$ siswa antusias jika pembelajaran matematika pada materi pecahan menggunakan media pembelajaran dengan menjawab "iya". Sebanyak 45,1\% siswa kurang antusias jika pembelajaran matematika menggunakan media dengan menjawab "tidak". 67,7\% siswa suka jika pembelajaran matematika pada materi pecahan dibuat dalam bentuk media majalah dengan menjawab "iya". 32,2\% siswa kurang setuju jika materi pecahan dibuat dalam bentuk majalah dengan menjawab "tidak". 77,4\% siswa setuju jika media pembelajaran pada materi pecahan dibuat menarik dengan menjawab "iya". $22,5 \%$ siswa tidak setuju jika media pembelajaran materi pecahan dibuat menarik dengan menjawab "tidak". 80,6\% siswa sangat semangat jika menggunakan media pembelajaran yang menarik dengan menjawab "iya" sedangkan 19,3\% siswa kurang semangat jika menggunakan media yang menarik dengan menjawab "tidak". Hal tersebut menunjukan bahwa media pembelajaran sangat dibutuhkan siswa dan guru dalam kegiatan belajar mengajar di kelas.

Berdasarkan hasil penelitian, peneliti dapat memperoleh data penelitian dan pembahasan tentang " Pengembangan Media MAJAMAT Pada Materi Pecahan Pada Mata Pelajaran Matematika Kelas V SDN Sitirejo Kabupaten Blora". Sebelum melakukan penelitian, peneliti melakukan observasi terlebih dahulu ke sekolah, untuk mengetahui masalah-masalah apa saja yang ada di sekolah tersebut. Setelah peneliti mengetahui permasalahannya, peneliti melakukan wawancara dengan guru kelas dan sebagian siswa yang akan diteliti. Penelitian dilakukan di kelas V dengan jumlah siswa sebanyak 31 siswa. Dari penelitian yang dilakukan oleh peneliti diperoleh hasil melalui angket respon siswa dan angket repon guru mengenai 
tanggapan tentang media MAJAMAT yang digunakan dalam kegiatan belajar di kelas. Media pembelajaran MAJAMAT mendapatkan respon dari guru sebesar $90 \%$ berdasarkan angket respon guru, dan media juga mendapatka respon siswa sebesar 90,58\%. Kedua nilai tersebut terletak pada interval 81\%-100\% dan termasuk kategori "sangat layak digunakan". Artinya media MAJAMAT layak digunakan sebagai media pembelajaran matematika di SD dan dapat diterima oleh guru maupun siswa kelas V SD. Selain respo siswa dan guru sebelum peneliti melakukan penelitian media MAJAMAT telah melakukan validasi media dan materi untuk mengetahui kelayakan dari media MAJAMAT yang digunakan oleh peneliti. Hasil dari Hasil penilaian rata-rata validasi ahli materi dan ahli media pembelajaran adalah sebesar 93,1\%. Nilai tersebut berada pada interval 81\%-100\% dengan kategori "sangat layak digunakan". Artinya media MAJAMAT layak digunakan sebagai media pembelajaran matematika di SD.

Penelitian dan pengembangan adalah suatu proses menciptakan inovasi baru dalam pendidikan yang berfungsi untuk memperbaiki permasalahan siswa dikelas berdasarkan kebutuhan siswa. Berdasarkan penguatan tersebut, metode ini sesuai dengan penelitian yang dilakukan oleh peneliti karena menghasilkan sebuah produk yang berupa media pembelajaran MAJAMAT. Media MAJAMAT dikembangkan dengan dasar majalah yang dirombak menjadi sebuah media pembelajaran. Media ini diciptakan berdasarkan permasalahan yang ada di SDN Sitirejo kecamatan Tunjungan Kabupaten Blora. Media MAJAMAT divalidasi oleh 1 ahli media pembelajaran dan 1 ahli materi pembelajaran untuk menilai kelayakan sebelum media digunakan di SD. Validator dipilih dari dosen Pendidikan Guru Sekolah Dasar Fakultas Ilmu Pendidikan Universitas PGRI Semarang yang berkompeten dan sesuai bidangnya. Dari hasil penilaian ahli materi dan media pembelajaran dapat menjadi acuan dalam pengembangan media. Selain itu untuk mengetahui kelayakan produk/kevalidan produk, peneliti melakukan penelitian di SDN Sitirejo Kecamatan Tunjungan Kabupaten Blora. Setelah peneliti melakukan penelitian kemudian peneliti membagikan angket respon guru dan respon siswa. Angket ini digunkan untuk mengukur respon siswa dan guru dalam menerima media MAJAMAT.

Pada penelitian media MAJAMAT sebelum media dirancang peneliti melakukan studi pendahuluan di SD untuk memperoleh permasalahan yang ada di SD. permasalahan diperoleh melaui wawancara dengan guru kelas dan membagikan angket kebutuhan siswa dan guru. Dari hasil wawancara telah diperoleh permasalahan di kelas diantaranya siswa masih sulit dalam berkonsentrasi saat pembelajaran dan guru masih kurang dalam mengaplikasikan media di kelas, sehingga membuat siswa merasa jenuh dan akhirnya bicara sendiri di kelas. Setelah peneliti menemukan permaslahan yang ada di SD barulah peneliti merancang atau mendesain sebuah media yang disebut media MAJAMAT untuk mengatasi permasalahan di SD. Media MAJAMAT merupakan sebuah media yang merupakan rombakan dari majalah yang dibuat menjadi media yang menarik dengan melengkapi materi dengan gambar-gambar yang menarik dan sesuai dengan materi, kemudian dibagian halaman akhir terdapat kantung soal yang bertujuan untuk mengetahu siswa sudah paham atau belum dengan materi yang disampaikan. Selanjutnya adalah langkah pengembangan yaitu peneliti mengembangkan isi dalam media MAJAMAT, mengidentifikasi kompetensi inti dan kompetensi dasar, menyusun RPP ( Rencana Pelaksanaan Pembelajaran), Validasi media dan materi pembelajaran. Berdasakan saran dari ahli materi dan ahli media pembelajaran media dapat diperbaiki kekurangan-kekurangannya. Media pembelajaran MAJAMAT divalidasi oleh Bapak Singgih Adhi P., S.Sn.,M.Pd sebagai ahli media pembelajaran dan Bapak M. Yusuf Setya Wardana.S.Pd.,M.Pd. Berdasarkan penilaian kedua validator maka diperoleh rata-rata persentase sebesar 93,1\%. Skor tersebut terletak pada interval 81\%-100\% dengan kategori "sangat layak digunakan" yang artinya media MAJAMAT layak digunakan untuk penelitian di SD. Setelah media MAJAMAT selesai dibuat dan divalidasi oleh ahli media dan materi dan telah melalui beberapa revisi oleh ahli media dan ahli materi pembelajaran. Maka tahap selanjutnya peneliti melakukan penelitian di SDN Sitirejo Kecamatan Tunjungan Kabupaten Blora. Pada saaat penelitian peneliti menerapkan angket respon guru dan siswa. Penerapan angket respon guru dan siswa dilakukan setelah peneliti selesai melakukan penelitian. Tahapan terakhir setelah selesai penelitian kemudian peneliti merekap data yang diperoleh dalam pengisian angket respon siswa kelas V SDN Sitirejo Kecamatan Tunjungan Kabupaten Blora adalah sebesar 90,58\% dari 31 siswa yang mana hasil tersebut terletak pada interval 81\%-100\% dengan kriteria "sangat layak digunakan". Kemudian perhitungan angket respon guru kelas V SDN Sitirejo Kecamatan Tunjungan Kabupaten Blora adalah sebesar 90\% yang terletak pada interval 81\%-100\% dengan kriteria "sangat layak digunkan". Berdasarkan penilaian tersebut, peneliti dapat menyimpulkan bahwa media MAJAMAT layak dan dapat diterima oleh guru dan siswa SD dalam proses pembelajaran. 


\section{KESIMPULAN}

Berdasarkan hasil penelitian dan pengembangan media MAJAMAT dapat disimpulkan bahwa:

1. Media MAJAMAT dikembangkan dengan cara memilih materi yang akan ditetapkan, disini peneliti memilih materi pecahan karena dari hasil wawancara guru kelas bahwa siswa susah membedakan antara rumus perkalian pecahan dengan pembagian pecahan.

2. Media pembelajaran MAJAMAT memiliki hasil rata-rata ahli materi dan ahli media pembelajaran sebesar 93,1\%. Skor tersebut terletak pada interval $81 \%-100 \%$ dengan kategori "sangat layak digunakan" yang artinya media MAJAMAT layak digunakan untuk penelitian di SD.

3. Media MAJAMAT mendapatkan respon dari guru dan siswa, hasil penilaian angket respon siswa kelas V SDN Sitirejo Kecamatan Tunjungan Kabupaten Blora adalah sebesar 90,58\% dari 31 siswa yang mana hasil tersebut terletak pada interval $81 \%-100 \%$ dengan kriteria "sangat layak digunakan". Kemudian perhitungan angket respon guru kelas V SDN Sitirejo Kecamatan Tunjungan Kabupaten Blora adalah sebesar 90\% yang terletak pada interval $81 \%-100 \%$ dengan kriteria "sangat layak digunkan". Berdasarkan penilaian tersebut, peneliti dapat menyimpulkan bahwa media MAJAMAT layak dan dapat diterima oleh guru dan siswa SD dalam proses pembelajar.

\section{DAFTAR PUSTAKA}

Adam, Steffi. 2015. Pemanfaatan Media Pembelajaran Berbasis Teknologi Informasi Bagi Siswa Kelas X Sma Ananda Batam . Journal Universitas Putera Batam Volume 3 No 2, ISSN 2337-8794

Alin, Dyahsih. 2015. Keefektifan Experiential Learning Pembelajaran Matematika Mts Materi Bangun Ruang Sisi Datar . Jurnal Riset Pendidikan Matematika Volume 2 - Nomor 2, November 2015, $(175$ - 185)

Arsyad, Azhar. 2011. Media Pembelajaran. Jakarta: PT Raja Grafindo Persada.

Daryanto. 2013. Media Pembelajaran. Yogyakarta: Gava Media.

Heruman. 2007. Model Pembelajaran Matematika di Sekolah Dasar. Bandung: PT REMAJA ROSDAKARYA.

Kustandi, Cecep dan Bambang Sutjipto. 2011. Media Pembelajaran. Bogor: Ghalia Indonesia.

Lintiasri, Suci. 2016. "Pengembangan Media Pembelajaran Imajinatif (Majalah Pintar Edukatif) Pada Pembelajaran IPA Siswa Kelas I SDN 01 Jagalan Kecamatan Karangnongko Kabupaten Klaten". Skripsi. Universitas PGRI Semarang.

Masitoh, Siti. 2017. "Pengembangan Media Pembelajaran MAJALIPACUA IPA Kelas III Sekolah Dasar". Skripsi. Universitas PGRI Semarang.

Munadi, Yudi. 2013.Media Pembelajaran sebuah Pendekatan Baru. Jakarta: Referensi.

Munirah. 2015. Sistem Pendidikan Di Indonesia: antara keinginan dan realita . Jurnal Auladuna, Vol. 2 No. 2 Desember 2015: 233-245

Palupi, Dini. 2018. Pendidikan Karakter Pada Anak Sekolah Dasar di Era Digital . Jurnal Pendidikan Dasar vol. 2, no. 1, 2018

Putra, Nusa. 2015. Research \& Development Penelitian dan Pengembangan: Suatu Pengantar. Jakarta : PT Raja Grafindo Persada.

Selviani, Siska dan Welly Anggraini. 2018. " Pengembangan Media Pembelajaran Majalah Fisika Sebagai Suplemen Pembelajaran Terintegrasi Nilai Keislaman". Indonesian Journal of Science and Mathematics Education. 01. Hal 79-87.

Sisdiknas. 2003. “Undang-undang Sistem Pendidikan Nasional: UU RI No. 20 Tahun 2003.

Siti, Aas . 2018. Teori-Teori Pendidikan Dalam Al-Qur'an . Jurnal Pendidikan Islam Vol.07, No. 1 ISSN : $2252-8970$

Shabir, M. 2015. Kedudukan Guru Sebagai Pendidik. Jurnal Auladuna, Vol. 2 No. 2 Desember 2015

Slameto. 2010. Belajar dan Faktor-faktor yang mempengaruhinya. Jakarta: Rineka Cipta. 
Sudharto, dkk. 2015. Pengantar Ilmu Pendidikan. Semarang: FIP IKIP PGRI Semarang.

Sudjana, Nana dan Ahmad Rivai. 2017. Media Pengajaran. Bandung: Sinar Baru Algensindo.

Sugiyono. 2011. Metode Penelitian Kuantitatif, Kualitatif dan R\&D. Bandung: Alfabeta.

Susanto, Ahmad. 2016. Teori Belajar dan Pembelajaran di Sekolah Dasar. Jakarta: Prenadamedia Group. 